\title{
Pulse Recovery of Soccer Football Athletes PSTS Tabing City of Padang Age 13-15 Years
}

\author{
Hadi pery Fajri ${ }^{1 *}$ and Andri Gemaini ${ }^{2}$ \\ ${ }^{1,2}$ Faculty of Sports Sciences, Universitas Negeri Padang Padang, Indonesia \\ ${ }^{*}$ Corresponding author. Email: hadiperyfajri@fik.unp.ac.id
}

\begin{abstract}
This study aims to determine the pulse rate of recovery of PSTS Tabing soccer athletes in Padang City Age Group 1315 Years. This research was conducted at the Padang Tabing City PSTS soccer field. The time of the study was conducted on July 3, 2019. This study used a descriptive research method, with the sample used was purposive sampling with a sample of 16 male soccer athletes in the age group 13-15 years of PSTS Tabing Padang City. Data collection techniques are done by testing and documentation. From the results of this study indicate: 1) The average pulse rate of recovery of PSTS Tabing soccer athletes in Padang City Group 13-15 Years Age is at a good classification level (81.25\%). 2) From the total sample of 16 people, there were 2 soccer athletes from PSTS Tabing Kota Padang in the 13-15 Years Age Group who had a very good recovery rate. 3) Of the total sample of 16 people, there were 13 soccer athletes PSTS Tabing Padang City Age Group 13-15 Years had a good recovery rate of recovery.
\end{abstract}

Keywords: Instrument test, Kick, Dollyo chagi

\section{INTRODUCTION}

One of the determining factors in achieving achievement is a good ability to decrease the recovery rate. If an athlete has a good ability to reduce the pulse of recovery, it will greatly assist the athlete in achieving achievements. The pulse is a wave that is felt in the arteries caused by the pumping of blood by the heart into the blood vessels. The pulse can be felt or palpated in arteries that are close to the surface of the body, such as temporal artery located above the temporal bone, dorsalis pedis artery located at the bend of the ankle, brachial artery located in front of the folds of the elbow joint, radial artery located in front of the wrist hands, and carotid arteries located at the height of the thyroid cartilage. The pulse rate for normal people is the same as the heart rate. Heart rate can easily be measured by measuring the pulse rate.

Table 1 . The normality of a men's recovery pulse

\begin{tabular}{|c|c|c|c|}
\hline Klasifikasi & $6-17$ th & $18-26$ th & $27-60$ th \\
\hline Superior & -74 & -68 & -69 \\
\hline Excellent & $75-83$ & $69-75$ & $70-78$ \\
\hline Good & $84-92$ & $76-83$ & $79-87$ \\
\hline Average & $93-103$ & $84-92$ & $88-99$ \\
\hline Far & $104-112$ & $93-99$ & $100-107$ \\
\hline Poor & $113-121$ & $100-106$ & $108-115$ \\
\hline Very Poor & $122 \geq$ & $107 \geq$ & $116 \geq$ \\
\hline
\end{tabular}

PSTS (Tabing Football Association and Surrounding Areas) is one of the soccer clubs in the city of Padang.
Padang city PSTS was established in 1975. Padang city PSTS is a place for the development of young soccer athletes who live in the city of Padang, starting from U10, U12, U15, U18, U21, U23 and seniors. PSTS Padang city is trained by Yulian Syahreva who already has a C AFC license. Padang PSTS has already won a championship at various events held by Padang Archipelago.

Based on observations that have been made at PSTS Padang city, the training program at PSTS Padang city includes endurance, speed, strength and game patterns. Based on observations that have been made in the PSTS Padang city researchers want to know how the condition of the recovery pulse of PSTS Tabing athletes in Padang.

\section{METHODS}

This type of research is classified into descriptive research. Descriptive research is research conducted to collect data and describe the object under study as it is. The purpose of this descriptive study is to make a description, profile, picture, in fact and truth encountered in the field.

In this study, it will be revealed or illustrated about the state of the recovery pulse of PSTS Tabing Age 13-15 year old soccer athletes in Padang City. This research was conducted at Tabing soccer field, Padang. While the time of the study was carried out in July 
2019. The sample in the study was U15 athletes, totaling 16 people.

\section{RESULT}

Pulse recovery index of PSTS Tabing soccer athletes in Padang City Group 13-15 years old through kash pulse recavery test obtained the highest Index value (Maximum) 80 and the lowest (Minimum) 96. From the distribution of data this Index obtained an average (Mean) 88.5, the middle index value (Median) is 90 , the most common index value (mode) is 92 . Meanwhile the standard deviation of the distribution of the recovery pulse index is 4.82 .

From the PSTS Tabing soccer athletes in Padang City aged 13-15 years, 2 athletes (12.5\%) had a very good recovery rate. Thirteen athletes $(81.25 \%)$ had a good recovery rate. And 1 athlete $(6.25 \%)$ had a sufficient recovery rate.

The recovery rate of PSTS soccer athletes Tabing Age Group 13-15 Years Padang City on average is in the level of good recovery pulse classification. Many things that affect the frequency of the pulse include; gender, age, body position, and physical activity.

\section{CONCLUSION}

Based on the results of the research described in the previous chapter it can be concluded that:

1) The average pulse rate of recovery of PSTS Tabing soccer athletes in Padang City Age Group 13-15 Years is at a good classification level (81.25\%).
2) From the total sample of 16 people, there were 2 soccer athletes PSTS Tabing Padang City Age Group 13-15 years had a very good recovery rate.

3) From the total sample of 16 people, there were 13 soccer athletes from PSTS Tabing Kota Padang, 13-15 years old who had a good recovery rate.

\section{REFERENCES}

[1] Apri Agus. (2012). Olahraga Kebugaran Jasmani. Padang: Sukabina Press.

[2] Bafirman. (2013). Fisiologi Olahraga. Malang: Wineka Media

[3] Brian J Sharkey. (2011). Kebugaran \& Kesehatan. Jakarta: Rajawali Pers.

[4] Christophe Hausswirth. (2013). Recovery for Peformance In Sport.

[5] Sazeli Rifki. (2011). Faktor-faktor yang Berhubungan Pulih Asal (Recovery). Universitas Negeri Padang. Jurnal

[6] Sucipto, dkk. (2000). Sepak Bola Latihan dan Strategi. Jakarta : Jaya Pura.

[7] Sugiyono. (2012). Statistika untuk Penelitian. Bandung : Alfabeta

[8] (2017). Metode Penelitian Kombinasi (Mixed Methods). Bandung: Alfabeta. Hal. 110-118.

[9] Suharsimi Arikunto. (2010). Prosedur Penelitian (suatu pendekatan praktik). Rev.ed Jakarta : PT. Rineka Cipta.

[10] Widiastuti. (2011). Tes dan Pengukuran Olahraga. Jakarta:PT BUMI TIMUR JAYA

[11] Yulifri \& Arsil. (2016). Permainan sepakbola. Padang : FIK UNP. 